\title{
側方運動時の咬合型別にみた正常者の咀嚼運動 Chewing Movements in the Types of Occlusion classified by Lateral Excursions in Normal Subjects
}

\section{一曲署筋筋活動について一}

- EMG Activity of Masticatory Muscles -

志賀博, 秋山志, 小林義典

Hiroshi SHIGA, Hitoshi ARIYAMA, and Yoshinori KOBAYASHI

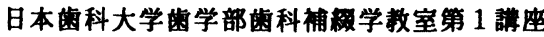

The Nippon Dental University, School of Dentistry at Tokyo, Department of Partial and Complete Denture

\section{1. 緒官}

著者らは、適切な側方運動時の晈合型を究明 する目的で、教室で開発した咀嚼運動自動分析 システム 哷運動との機能的関係を検索している。すでに、 正常者を咬合型により犬畨誘導群とgroup function群の 2 群に分け、片側ごとにガム咀 嘫を行わせ、運動経路、運動リス厶、速度成分、 筋活動などを比較検討した結果、閉口時では 犬菌誘導群、group function群ともに比校的安 定した咀嚼運動を呈するが、開口時ではgroup function群の方が犬歯誘導群よりも不安定であ ることなどを報告してきた ${ }^{2-7) 。 ~}$

今回は、正常者の咀哷運動時の咀嶰筋活動 における側方運動時の咬合型別の差異を明確に する目的で、咀㛵運動時の咀嚼筋筋活動につい て、犬菌誘導群とgroup function群との間で比 較した。

\section{2. 研究方法}

\section{1 被釦者と被験食品}

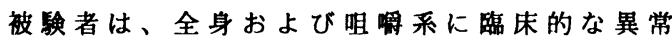
が認められない22〜28歲の日本菌科大学菌学部 の学生および職員のなかから、側方運動時の咬 合型が典型的な犬歯誘導群である14名と、同様 にgroup function群である14名を選択した。

被験食品は、ワーナー・ランバート社製の チューイン・ガム 1 枚を測定前に約 1 分間咀謝 させ、軟化したものを用いた。

\section{2 記録方法および装膡}

筇電図の記録は、シールドルームにおいて被 娩者を药科用治療椅子に坐らせ、頭部を固定せ ずにフランクフルト平面が水平になるように、 またリラックスさせた後、できる限り自然な状 態で行った。

被凂筋は、両側の側頭筇前部（ $\mathrm{Ta}$ ）および咬 筋中央部 $(\mathrm{Mm})$ の 4 筋で、電極間医離を $18 \mathrm{~mm}$ 固定した直径 $10 \mathrm{~mm}$ の銀製血電極を貼付し、双極 誘導した。

導出した現象は、日本光電社製多用途計測記 録装監（RM6000）を用いて、時定数を 0.03 秒と して同社製インク書きオシログラフで $1 \mathrm{mV}$ 入 力に対しペンの振れが $10 \mathrm{~mm}$ とるように增幅度 を更生した後、被験者に片側でチューインガム を無下させずに30ストローク咀嚼させ、E M G 信号を TEAC社製データレコーダー（XR50）に記 録した。

\section{3 分析方法}

分析は、オシログラフペーパー上に再生した E M G 原波形を計測基準に従って、DEGIMATICCARIPER を用いて、被驗者の主咀唧側の咬筋と 側頭筋の咀嚼開始後第 5 ストロークからの10ス トローク（因 1 ）における能活動時間、筋活動 間隔時間、ならひに両者の和として表される cycle timeを計測後（因2）、それらの10スト ロークの平均值と变動係数を算出し、犬齿誘導 群とgroup function群との間で比較した。 


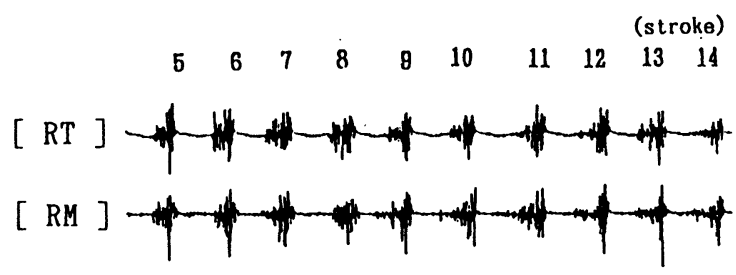

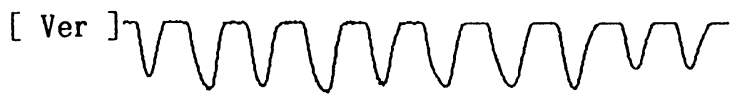

因 1 右側咀時における咀题開始後第 5 〜第14ストローク の側頭觔および咬筋能活動

$\mathrm{RT}$ ：右側側頭筋, RM：右側咬筋, Ver：運動の垂直成分

\section{3. 結果}

3.1 咬筇と側頭筇の飭活動時間の平均

筋活動時間の平均は、犬曾誘導群では咬脅が $244 \mathrm{msec}$ 、側頭筋が $235 \mathrm{msec}$,group function群 では咬筇が $268 \mathrm{msec、}$ 、側頭筋が $249 \mathrm{msec}$ で、咬筋、 側頭筋ともに两群間に有意差が認められなかっ たか、group function群の方が犬歯誘導群より も大きな值を示した（図 3 ）。

\section{2 咬筋と側頭筇の筋活動間隔時間の平均}

筋活動間隔時間の平均は、犬歯誘導群では咬 筋が $312 \mathrm{~ms} \mathrm{ec}$ 、側頭筋が $321 \mathrm{msec}$ であったが、 group function群では咬筇が $363 \mathrm{msec}$ 、側頭能 が $380 \mathrm{msec}$ で、咬能、側頭能ともにgroup function群の方が犬菌誘導群よりも著明に大き く、両群間に有意差が認められた（図4）。

\section{3 咬筋と側頭筋の cycle timeの平均}

Cycle timeの平均は、犬齿誘尊群では咬筋が $556 \mathrm{msec}$ 、側頭筋が $555 \mathrm{msec}$ であっだ、group function群では咬筋が $631 \mathrm{msec}$ 、側頭筋が 630 $\mathrm{msec}$ で、筋活動間隔時間と同様に咬筋、側頭筋 ともにgroup function群の方が犬菓誘導群より も著明に大きく、両群間に有意差が認められた （図 5 ）。

3.4 咬筋と側頭筋の筋活動時間の变動係数 觔活動時間の変動係数は、犬歯誘導群では咬 筋が $7.8 \%$ 、側頭筋が $8.7 \%$ あったが、group

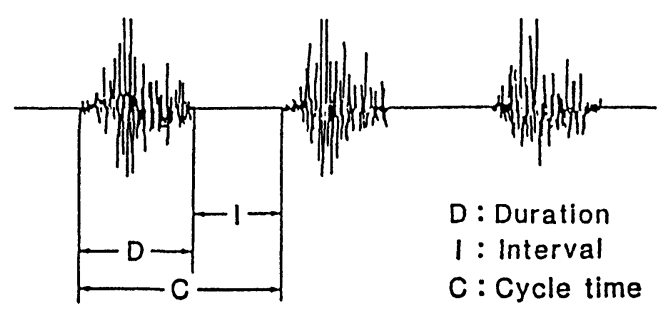

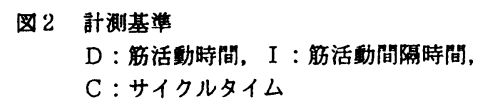

function群では咬筋が $10.0 \%$ 、側頭胳が $10.8 \%$ で、咬筋ではgroup function群の方が犬奥誘導 群よりも有意に大きな值を示した。一方、側 頭筋は、両群間に有意差が認められなかったが、 group function群の方が犬雪誘導群よりも大き な值を示した（因6）。

3.5 咬筋と側頭筋の筇活動間隔時間の変動係 数

筋活動間隔時間の変動係数は、犬菌誘導群で は咬筋が $7.6 \%$ 、㑡頭筇が $8.3 \%$ あったが、 group function群では咬筋が $10.3 \%$ 、側頭筋が $10.1 \%$ 、咬筇、側頭筋ともにgroup function 群の方が犬齿誘導群よりも大きな值を示し、 咬脅において両群間に有意差が認められた（困 7 )。

3.6 咬筋と側頭筋のcycle timeの変動係数 Cycle timeの変動係数は、犬菊誘導群では咬 筇が $4.7 \%$ 、側頭筋が $5.4 \%$ あったが、group

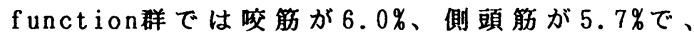
咬筇、側頭筋ともに両群間に有意差が認められ なかったが、group function群の方が犬㐘誘導 群よりも大きな值を示した（図8）。

次に、両群間における機能的差異が筋活動時 間よりも筋活動間隔時間において明瞭に現れる 原因を調べる目的で、各被験者ひ咬脇筋活動と 下額運動との関係について調べた。 


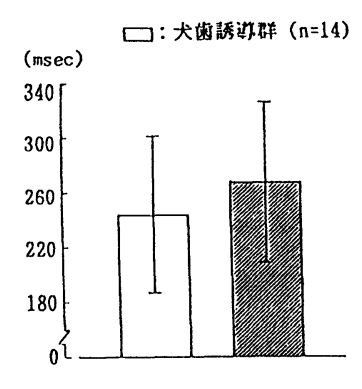

咬筋
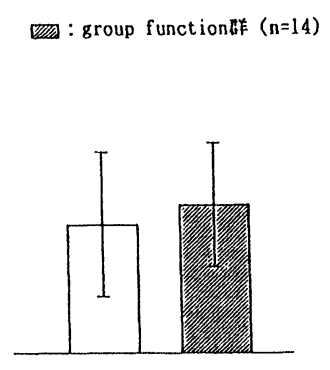

側頭筋

因 3 筋活動時間の平均

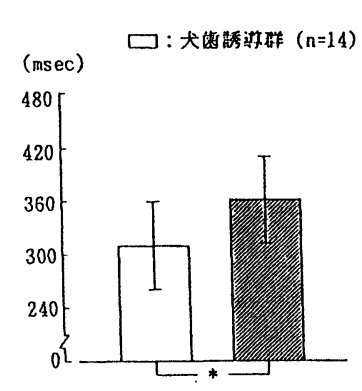

咬筋 [שea : group function b) $(n=14)$

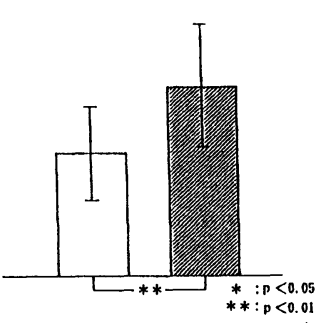

側頭筋

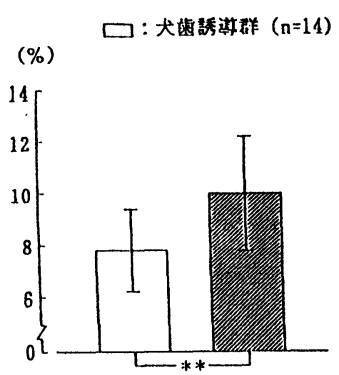

咬筋

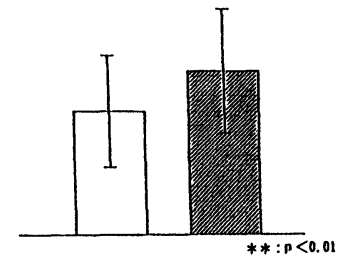

側頭筋

因6 觔活動時間の变動係数

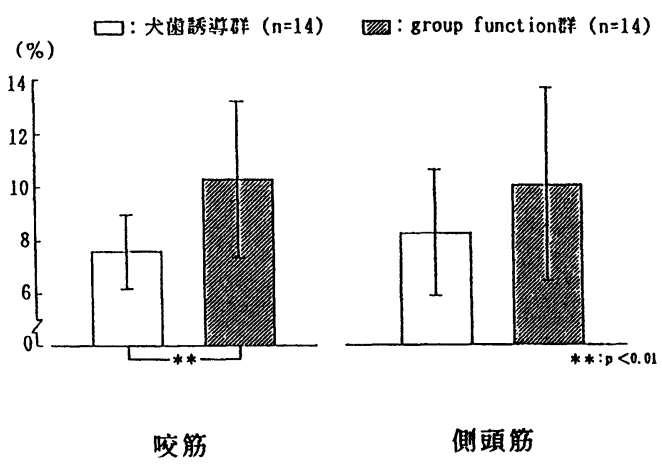

因 7 施活動間隔時間の変動係数
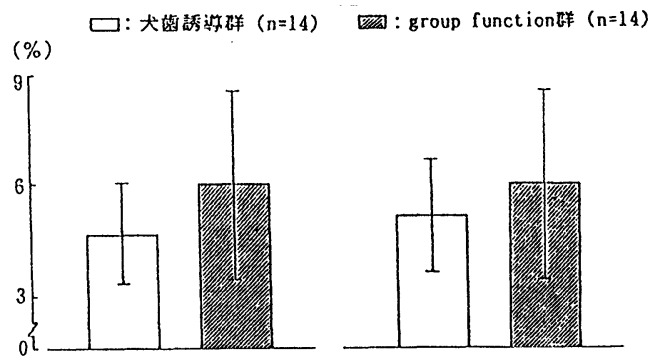

咬筋

側頭筋

3.7 咬筋の筇放電パターン

各被験者の筋放電パターンには若干の個人差
がみられたが、両群間に著明な差異は認められ なかった（図9-1,9-2）。 


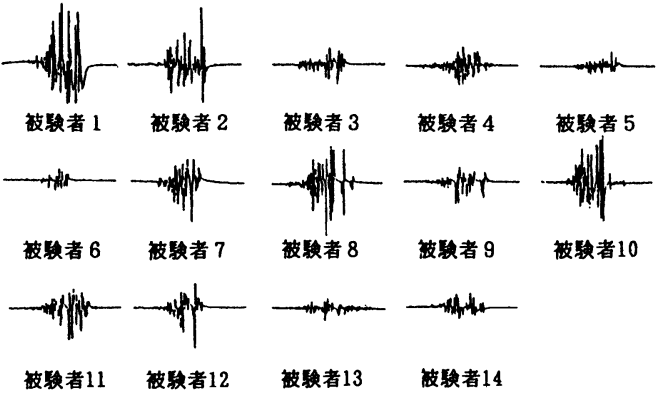

因9-1 犬柬誘湴群における咬筋の筋放電パターン

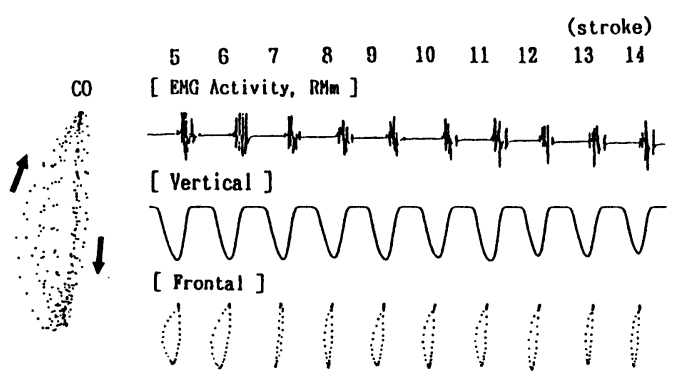

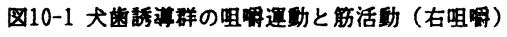

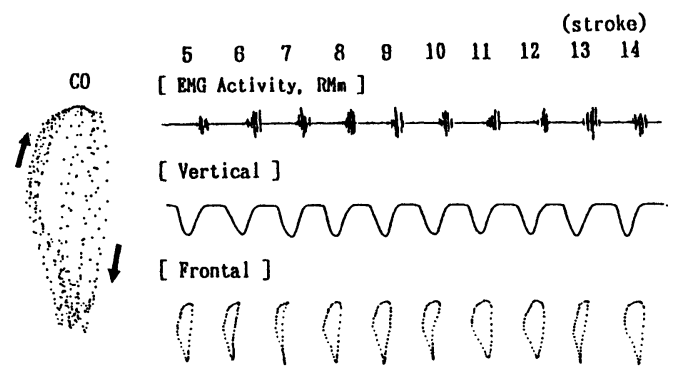

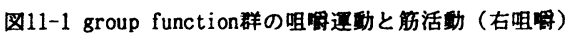

\section{8 咀惯運動経路と咬筇慨活動}

\section{8 .1 犬栽唀導群}

犬菌誘導群の咀㗂動は、中心咬合位から作 業側へスムーズに開口し、その後中心咬合位へ 戻る運動を呈していた。また、咬笳筋活動は、 最大開口位付近で開始し、咬合相中で終了して いた（因10-1，10-2）。

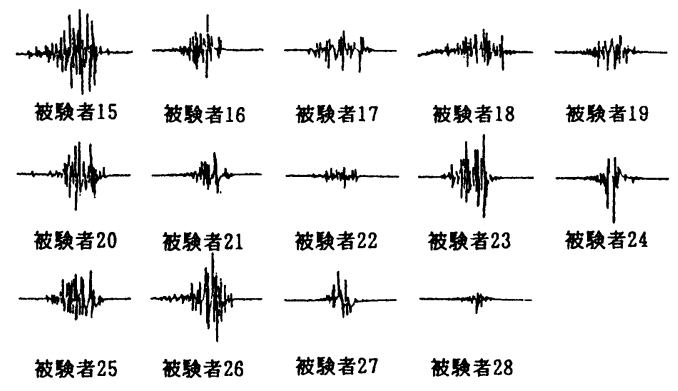

因9-2 group function群における咬筋の筋放電パターン

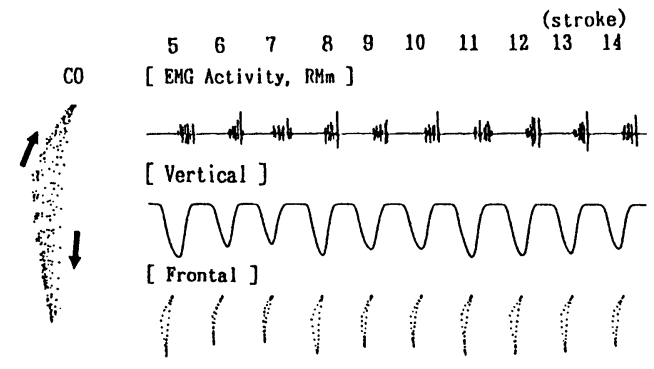

因10-2 犬迷誘導群の咀哷運動と筋活動（右咀哷）

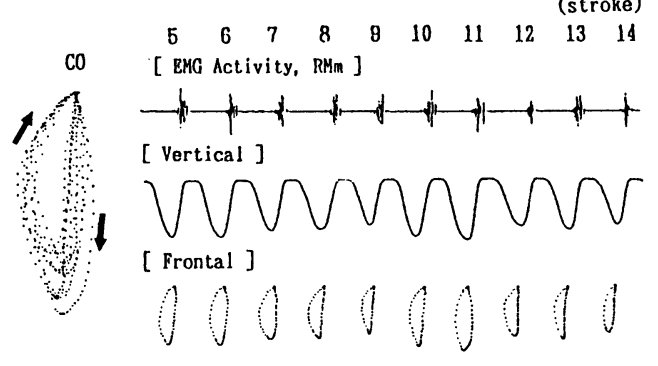

図11-2 group function群の咀哷運動と妫活動（右咀铜）

\subsubsection{Group function群}

Group function群の咀嚼運動は、中心咬合位 から非作業側へ開口後、作業側へ向かいその後 中心咬合位に䒝る場合（10名）と犬菌誘遒群と 同様に中心晈合位から作業側へスムーズに開口 しその後中心咬合位へ杘る場合（4名）とが観 察された（因11-1，11-2）。 
また、被験者 2 名の咬筋筋活動は、犬歯誘導 群の被験者と同様に最大開口位付近で開始し、 咬合相中で終了していた。

\section{4. 考察}

筋活動時間、筇活動間隔時間、cycle timeの 各平均は、咬筋、側頭筋ともにgroup function 群の方が犬齿誘導群よりも大きく、筋活動間隔 時間とcycle timeにおいて両群間に有意差が認 められた。一方、筋活動時間、筋活動間隔時間、 cycle timeの各変動係数は、それらの各平均と 同様に咬筋、側頭筋ともにgroup function群の

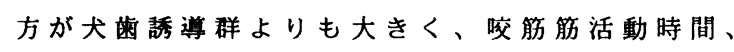
咬筇筋活動間隔時間において両群間に有意差が 認められた。

これらの結果は、咀䜊運動時の筋活動におい てgroup function群の方が犬菌誘導群よりも延 長傾向にあり、かつ不安定であることを示すも のと考えられる。また、その差異は、筋活動間 隔時間の方が筋活動時間よりも著明であった。 したがって、両群間の機能的差異は、筋活動時 間よりも筋活動間隔時間において明暸に現れる ものと考えられる。

咬筋筇活動は、犬歯誘導群、group function 群ともに若干の個人差を有するものの、ほほ同 じ筋放電パターンを呈し、かつ最大開口位付近 で開始し、咬合相中で終了することが判明した。 また、group function群における咬筋筋活動が 咬合相中で終了していたことから、咬筇笳活動 と非作業側への開口運動とは無関係であるとい える。すなわち、非作業側への開口運動は、咀 嚼動作にとつて必ずしも必要ではないものと考 えられる。

著者らは、すでに犬歯誘導群とgroup function群の開口路を調べ、中心咬合位から作 業側へスムーズに開口する犬歯誘導群では咀啤 運動のパターン形成が十分になされ、安定した 経路を呈するが、一般に中心咬合位から非作業 側へ向かうgroup function群では咀嚼運動のパ ターン形成が十分になされていないことが多い こと ${ }^{6)}$ 報告した。また、最大速度は、閉口時 では両群ともにほほ同じであるが、開口時では group function群の方が犬歯誘導群よりも有意

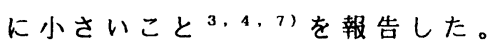

これらのことから、group function群におけ る非作業側への開口は、咀嚼運動を遅らせ、不 安定にし、パターン形成がされにくい無理な動 きであると考えてよいように思われる。また、 この開ロが、咀嘫筋筇活動の間隔時間内で行わ れるために、両群間に機能的差異が明瞭に現れ たものと考えられる。

\section{5. 結 論}

正常者の咀嘫運動時の咀嶰筋活動における 側方運動時の咬合型別の差異を明確にする目的

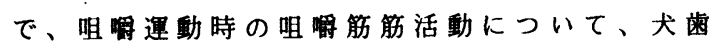
誘導群とgroup function群との間で比較した結 果、以下の結論を得た。

5.1 筋活動時間、筋活動間隔時間、cycle timeの各平均は、咬筋、側頭筋ともにgroup function群の方が犬歯誘導群よりも大きな值を 示し、筋活動間隔時間とcycle timeにおいて両 群間に有意差が認められた。

5.2 筋活動時間、筋活動間隔時間、cycle timeの各変動係数は、咬筋、側頭筋ともに group function群の方が犬歯誘導群よりも大き な值を示し、咬筋の筇活動時間と筋活動間隔時 間において両群間に有意差が認められた。

\section{3 咬筋の筋放電パターン}

各被験者の筋放電パターンには若干の個人差 がみられたが、両群間に著明な差異は諗められ なかった。

\section{4 咀㛵運動経路と咬筋筋活動}

咀謝運動は、犬歯誘導群ではすべて中心咬 合位から作業側へスムーズに開口し、その後 中心咬合位へ吴る運動を呈していたが、group function群では犬歯誘導群と同様な運動を呈す るのは少なく、多くが中心咬合位から非作業側 へ開口後、作業側入向かいその後中心咬合位に 戻る運動を呈していた。

\section{一方、咬筋笳活動は、犬菌誘導群、group} function群ともに最大開口位付近で開始し、咬 合相中で終了していた。 
5.5 以上のことから、咀嚼運動時の筋活動に おいてgroup function群の方が犬歯誘導群より も延長傾向にあり、かつ不安定であること、ま たこの機能的差異は、筋活動時間よりも筋活動 間隔時間において明瞭に現れるものと考えられ る。

6. 文献

1）志賀博，小林義典：咀嚼運動の分析によ る咀嚼機能の客㯒的評価に関する研究, 補程誌, 34:1112-1126, 1990 .

2）志賀博，石川忠，川口一夫，小林義典： 咀嚼運動の機能的分析一咬合型別にみた正常者 の咀嚼運動経路一, 補緅誌, 31：1302-1303, 1987.

3）志賀博, 秋山仁志, 小林義典：咀㗖運動 の機能的分析一咬合型別にみた正常者の咀唧運 動経路（その2）一，歯学，75：528-529，1987.

4) Shiga, H., Akiyama, H., and Kobayashi, Y. The analys is of chewing movements, The effect of the type of occlusion on the path of chewing movement in normal subjects (Part3), J Dent Res, 67: 738, 1988 .

5 ）志賀博, 小島健一郎, 山本勇, 小林義典 : 咀嚼運動の機能分析，第 7 報咬合型別に見た 咀嚼筋筋活動について，歯学，75：1200-1201, 1988 .

6）小林義典, 志賀博, 秋山仁志：側方運動 時の咬合型別にみた正常者の咀嘴運動一開口路 について一，補緅誌，34（第84回特別号）: 140,1990 .

7) Kobayashi, Y. and Shiga, H.:The masticatory movement of cuspid-guided and group function, J 0ral Rehabil, 17: 206-207, 1990. 